\title{
Infectious Diseases, Biodiversity and Global Changes: How the Biodiversity Sciences May Help
}

\author{
Serge Morand \\ Institut des Sciences de l'évolution, CNRS-IRD-UM2, CCO65 \\ Université de Montpellier 2 \\ France
}

\section{Introduction}

Biodiversity has been reduced on an unprecedented scale over the last decades (MEA, 2005). Concomitantly, new infectious diseases have emerged (or re-emerged) at an increasing rate (Wilcox \& Gubler, 2005; Jones et al., 2008) through human impacts on ecosystems, which are supposed to influence this (re-)emergence of diseases (Chivian \& Berstein, 2004; Patz et al. 2004). According to the Millenium Ecosystem Assessment (MEA, 2005), biodiversity helps at regulating diseases, with disease regulation as one of the services provided by ecosystems (Walpole et al., 2009). According to this report, high level of species diversity is supposed to reduce or to buffer the risk of disease transmission (MEA 2005).

However, greater overall biodiversity is often shown to be linked to a greater diversity of pathogens (Poulin \& Morand, 2004). Thereby, high biodiversity should be linked to high incidence of infectious diseases (Dunn et al., 2010). The reasons of the discrepancy between biodiversity loss and the increasing rate of infectious diseases and the persistence of numerous infectious diseases need a special attention on the likely mechanisms that could link biodiversity and infectious diseases.

Several studies provide evidences that support both of these views. Here, the main questions are how biodiversity is linked to infectious diseases, and how biodiversity sciences may help at improving health.

\section{The biodiversity of parasites and pathogens}

Although the terms pathogen and parasite are used in different scientific fields (human medicine, veterinary medicine, ecology) and may have different meanings (i.e. pathogens for micro-parasites such as viruses and parasites for macro-parasites such as worms), here we make the choice to use them as synonyms.

Parasites are found in all living organisms. Parasite diversity is estimated by the number of parasite species, but also is reflected in relation to their life cycles (direct, vector-transmitted) or their size (from a few micrometres to metres). More than $10 \%$ of the metazoan species that have been so far described are parasites (often referred as macro-parasites) (Poulin \& Morand, 2004). When micro-organisms are included (i.e. protozoans and pathogenic 
bacteriae, viruses, often referred as micro-parasites), parasites may represent more than half of all living species (de Meeûs \& Renaud, 2002). Then, no free-living species are free from infection. However, at an interspecific level, a great variability is observed among hosts, with few host species harbour high parasite species diversity and many other harbour less parasite diversity. Several studies have attempted to investigate the reasons of this variability by searching the likely determinants of parasite species richness. The likely explanations for this observed variability among free-living animals can be classified into five major groups of determinants (Table 1):

1. Macro-environmental determinants.

The biodiversity of plants or animals is highly correlated with some major gradients, such as latitudinal or altitudinal gradients. What about parasites? Do tropical regions host more parasites? The answers to this question highly depend on groups of parasites and/or groups of hosts. For example, the latitudinal gradient in parasite species richness was not observed in many mammalian parasites (such as endoparasitic worms or ectoparasitic arthropod (see Bordes et al., 2010). For humans, Guernier et al. (2004) found a strong positive correlation between proximity to the equator and parasite species richness (Fig. 1a). Moreover, they found that the maximum range of precipitation was the best correlated environmental variable with the species diversity of helminths, protozoa, fungi, and indirectly transmitted viruses. Lindenfors et al. (2007) for helminths and carnivores, and Krasnov et al. (2004) for fleas and rodents (Fig.1b) found opposite results with an increase of parasite species richness towards higher latitudes. Nunn et al. (2005) showed that parasite species richness increases toward lower latitudes only for protozoan parasites in Primates. Interestingly, the recent discovery of new Plasmodium species in primates and the potential risks for humans are in favour of non-human primate origins of Plasmodium falciparum (Rayner et al., 2011). Recently, Bordes et al. (2010), using a large data base on helminths in mammals, concluded on a lack of correlation between helminth diversity and latitude. All these studies that focused on mammal parasites suggest some special characteristic of human parasite diversity.

2. Epidemiological determinants.

Epidemiological models are used to estimate the success of invasion or spread, i.e. epidemic, of a parasite in a population of non-infected hosts. Several epidemiologicallyrelated factors may promote and facilitate the spread of parasite in a host population, such as host density. The application of theoretical epidemiological results to the study of parasite diversity has shown that for many animal groups, their species diversity in parasites is well connected to host density (expressed as individual numbers per unit area) (Arneberg et al. 1998; Torres et al., 2006). Epidemiological theory postulates also a positive effect of host longevity on parasite transmission, which however has rarely been found to influence parasite diversity (Linderfors et al., 2007).

3. Ecological determinants.

Some features of the ecology of host may facilitate transmission. The geographical range of host species has been hypothesized as a potential determinant of parasite species richness. In several groups of mammals, it was indeed shown that species richness of parasites is positively correlated with geographical range of their hosts (Linderfors et al., 2007). Home range, although less investigated, is hypothesized as a potential determinant, with the prediction that large home range should facilitate hostparasite contacts and then the increase of parasite diversity. However, Bordes et al. 
(2009) reported the opposite patterns in mammals where an increase in home range area is associated with a decrease in parasite species richness in carnivores, rodents and lagomorphs (Fig. 2). As they also showed that home range size is negatively correlated with host density in mammals, they hypothesized that the pattern observed was an epidemiological determinant. By increasing their home range area, mammals reduce their densities but also the transmission successes of their parasite.

A

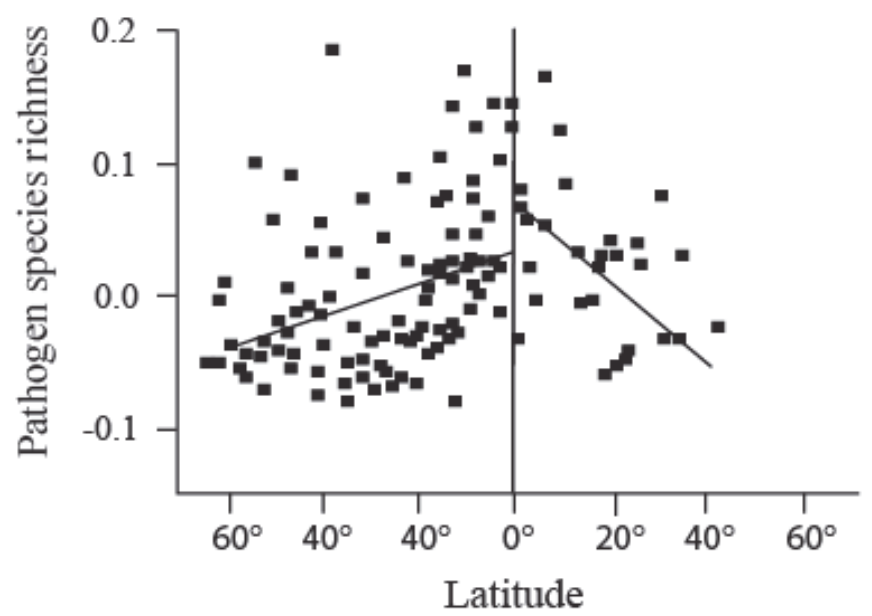

B

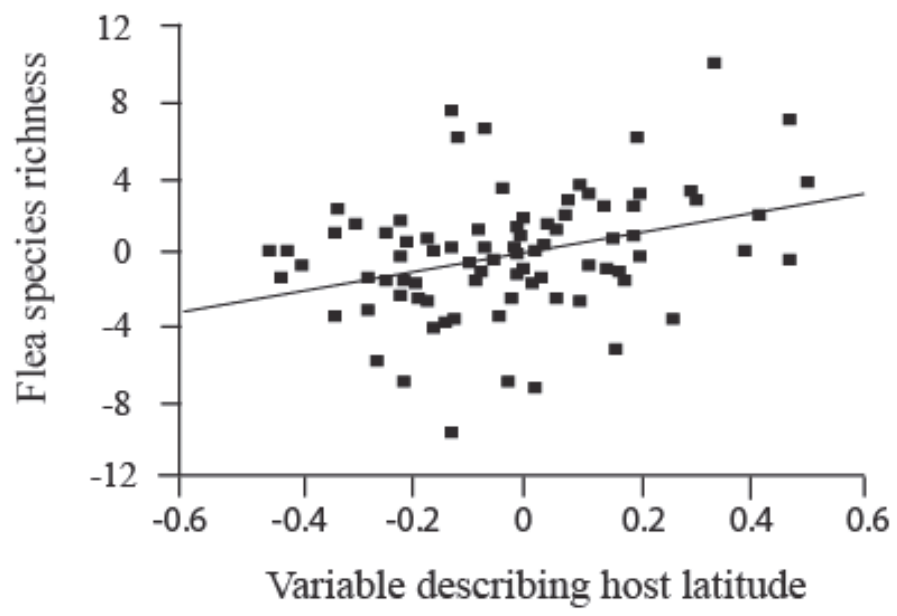

Fig. 1. The latitudinal gradients of parasite and pathogen species richness. (a) Relationship between pathogen species richness of humans and latitude of human populations sampled for pathogen infectious diseases across the two hemispheres (modified after Guernier et al., 2004); (b) relationship between flea species richness in rodents and the latitude of centre of geographic range (modified after Krasnov et al., 2004) 
4. Evolutionary determinants.

Host-parasite interactions occur in ecological time (on a relative small time scale). However, we must not forget that these interactions are also the result of an evolutionary history. Hence, a positive correlation between parasite diversity and diversification of their hosts has been observed in several host-parasite associations. Typically, host groups that harbour highly diverse parasite communities are also highly species diversified. However, there is no clear explanation. Either parasites can be the driving force of host diversification or they just follow their host diversification.

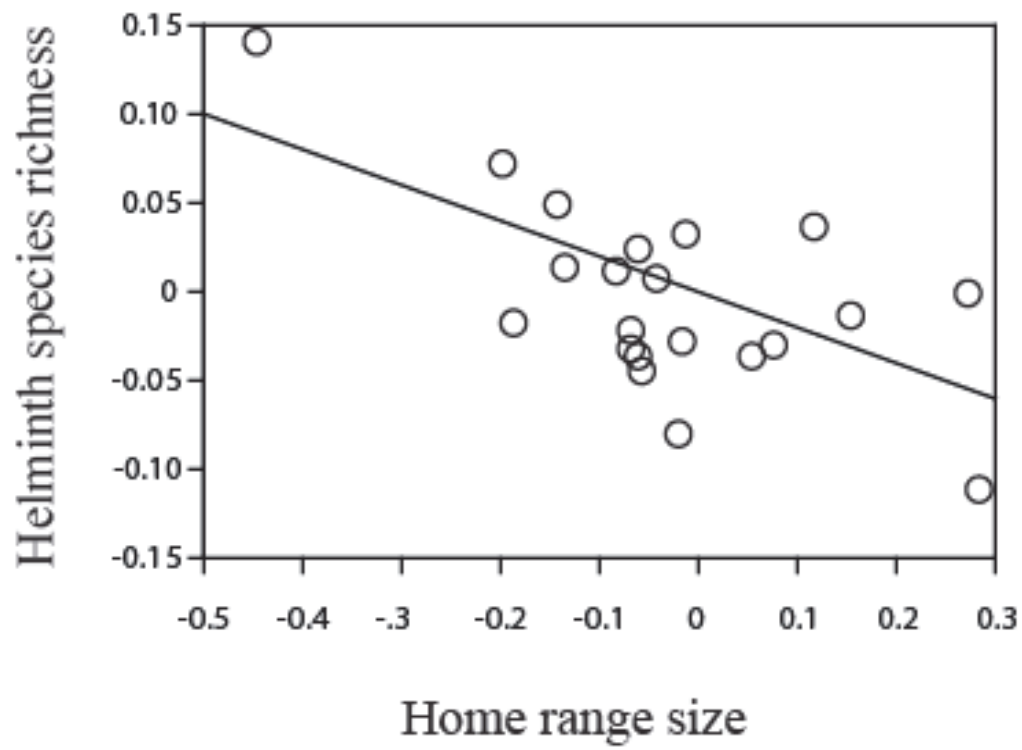

Fig. 2. Relationship between helminth species richness of carnivores and home range (modified after Bordes et al., 2009)

Bordes et al. (2007) found that the increase of social complexity in rodents is negatively correlated with ectoparasite species richness. They suggested that the evolution of sociality in rodents could be associated with behavioural traits that may reduce ectoparasitism load, such as allogrooming, or may increase parasite avoidance or dilute infection risks (but see Alitzer et al., 2003). 
Infectious Diseases, Biodiversity and Global Changes:

\begin{tabular}{|c|c|c|c|}
\hline Determinant & Organism & Correlation & Reference \\
\hline \multirow[t]{9}{*}{\begin{tabular}{|l|} 
Latitudinal gradient \\
\end{tabular}} & Helminths and mammals & No & Poulin (1995) \\
\hline & Helminths and mammals & No & Morand (2000) \\
\hline & Helminths and mammals & No & Bordes et al. (2010) \\
\hline & Helminths and primates & No & Nunn et al. (2005) \\
\hline & Helminths and carnivores & $\begin{array}{l}\text { Yes } \\
\text { (positive) }^{*}\end{array}$ & $\begin{array}{l}\text { Lindefors et al. } \\
(2007)\end{array}$ \\
\hline & Fleas and rodents & $\begin{array}{l}\text { Yes } \\
\text { (positive) }\end{array}$ & Krasnov et al. (2004) \\
\hline & Protozoans and primates & $\begin{array}{l}\text { Yes } \\
\text { (negative) }\end{array}$ & Nunn et al. (2005) \\
\hline & Microparasites and humans & $\begin{array}{l}\text { Yes } \\
\text { (negative) }\end{array}$ & $\begin{array}{l}\text { Guernier et al. } \\
(2004)\end{array}$ \\
\hline & Microparasites and rodents & $\begin{array}{l}\text { Yes } \\
\text { (negative) }\end{array}$ & Bordes et al. (2011) \\
\hline \multirow[t]{4}{*}{$\begin{array}{l}\text { Area size (geographic } \\
\text { distribution) }\end{array}$} & Helminths and rodents & $\begin{array}{l}\text { Yes } \\
\text { (positive) }\end{array}$ & Feliu et al. (1997) \\
\hline & Fleas and rodents & $\begin{array}{l}\text { Yes } \\
\text { (positive) }\end{array}$ & Krasnov et al. (2004) \\
\hline & Helminths and carnivores & $\begin{array}{l}\text { Yes } \\
\text { (positive) }\end{array}$ & Torres et al. (2006) \\
\hline & $\begin{array}{l}\text { Macro- , microparasites and } \\
\text { carnivores }\end{array}$ & $\begin{array}{l}\text { Yes } \\
\text { (positive) }\end{array}$ & $\begin{array}{l}\text { Lindefors et al. } \\
(2007)\end{array}$ \\
\hline \multirow[t]{4}{*}{ Host body size } & Helminths and mammals & No & $\begin{array}{l}\text { Morand \& Poulin } \\
\text { (1997) }\end{array}$ \\
\hline & Helminths and rodents & No & Feliu et al. (1998) \\
\hline & $\begin{array}{l}\text { Macro- , microparasites and } \\
\text { primates }\end{array}$ & No & Nunn et al. (2003) \\
\hline & $\begin{array}{l}\text { Macro- , microparasites and } \\
\text { ungulates }\end{array}$ & $\begin{array}{l}\text { Yes } \\
\text { (positive) }\end{array}$ & Ezenwa et al. (2006) \\
\hline \multirow[t]{6}{*}{ Host density } & Helminths and mammals & $\begin{array}{l}\text { Yes } \\
\text { (positive) }\end{array}$ & $\begin{array}{l}\text { Morand \& Poulin } \\
(1998)\end{array}$ \\
\hline & Nematodes and mammals & $\begin{array}{l}\text { Yes } \\
\text { (positive) }\end{array}$ & Arneberg (2002) \\
\hline & $\begin{array}{l}\text { Fleas and rodents and } \\
\text { insectivores }\end{array}$ & $\begin{array}{l}\text { Yes } \\
\text { (positive) }\end{array}$ & Stanko et al. (2002) \\
\hline & Helminths and primates & $\begin{array}{l}\text { Yes } \\
\text { (positive) }\end{array}$ & Nunn et al. (2003) \\
\hline & Helminths and carnivores & $\begin{array}{l}\text { Yes } \\
\text { (positive) }\end{array}$ & Torres et al. (2006) \\
\hline & $\begin{array}{l}\text { Macro-, microparasites and } \\
\text { carnivores }\end{array}$ & $\begin{array}{l}\text { Yes } \\
\text { (positive) }\end{array}$ & $\begin{array}{l}\text { Lindefors et al. } \\
(2007)\end{array}$ \\
\hline \multirow[t]{3}{*}{ Host longevity } & Helminths and mammals & $\begin{array}{l}\text { Yes } \\
\text { (positive) }\end{array}$ & $\begin{array}{l}\text { Morand \& Harvey } \\
(2000)\end{array}$ \\
\hline & $\begin{array}{l}\text { Fleas and rodents and } \\
\text { insectivores }\end{array}$ & No & Stanko et al. (2002) \\
\hline & Helminths and carnivores & No & Torres et al. (2006) \\
\hline
\end{tabular}




\begin{tabular}{|c|c|c|c|}
\hline & $\begin{array}{l}\text { Macro- , microparasites and } \\
\text { ungulates }\end{array}$ & $\begin{array}{l}\text { Yes } \\
\text { (positive) }\end{array}$ & Ezenwa et al. (2006) \\
\hline \multirow[t]{2}{*}{ Group size } & $\begin{array}{l}\text { Macro- , microparasites and } \\
\text { primates }\end{array}$ & No & Nunn et al. (2003) \\
\hline & $\begin{array}{l}\text { Macro- , microparasites and } \\
\text { ungulates }\end{array}$ & $\begin{array}{l}\begin{array}{l}\text { Yes } \\
\text { (negative) }\end{array} \\
\end{array}$ & Ezenwa et al. (2006) \\
\hline \multirow[t]{2}{*}{ Host sociality } & Helminths and rodents & No & Bordes et al. (2007) \\
\hline & $\begin{array}{l}\text { Ectoparasitic arthropods and } \\
\text { rodents }\end{array}$ & Yes & Bordes et al. (2007) \\
\hline \multirow[t]{6}{*}{ Home range } & Helminths and primates & $\begin{array}{l}\text { Yes } \\
\text { (negative) }\end{array}$ & Nunn et al. (2003) \\
\hline & Helminths and ungulates & No & Ezenwa et al. (2006) \\
\hline & $\begin{array}{l}\text { Direct-transmitted parasites } \\
\text { and carnivores }\end{array}$ & $\begin{array}{l}\text { Yes } \\
\text { (negative) }\end{array}$ & $\begin{array}{l}\text { Lindefors et al. } \\
(2007)\end{array}$ \\
\hline & Helminths and ungulates & No & Bordes et al. (2009) \\
\hline & Helminths and carnivores & $\begin{array}{l}\text { Yes } \\
\text { (negative) }\end{array}$ & Bordes et al. (2009) \\
\hline & Helminths and glires & $\begin{array}{l}\text { Yes } \\
\text { (negative) }\end{array}$ & Bordes et al. (2009) \\
\hline $\begin{array}{l}\text { Host genetic diversity } \\
\text { (MHC) }\end{array}$ & Helminths and rodents & Yes & $\begin{array}{l}\text { Goüy de Bellocq et } \\
\text { al. (2008) }\end{array}$ \\
\hline $\begin{array}{l}\text { Host genetic diversity } \\
\text { (HLA) }\end{array}$ & Virus and humans & Yes & $\begin{array}{l}\text { Prugnolle et al. } \\
(2005)\end{array}$ \\
\hline Anthropization gradient & Helminths and rodents & Yes & Chaisiri et al. (2010) \\
\hline
\end{tabular}

Table 1. Some examples of determinants of parasite diversity ( ${ }^{*}$ opposite trend as expected) of mammals (humans included)

\section{Global change, biodiversity and pathogens}

Global changes are the results of increases in all factors of anthropogenetic origins: atmospheric conditions, land uses, over-exploitation of resources, biotic invasions and pollutants. Global changes affect biodiversity by increasing the rate of extinction, by modifying the functioning of ecosystems and then by affecting the health of plants, animals and humans.

\subsection{Climate change}

Climate change is altering the ecology of pathogens, and the interactions among hosts and their pathogens (Shope, 1991; Patz et al., 1996, 2000; Sutherst, 1998, 2001, 2004; Rogers \& Randolph, 2000; Kovats et al., 2001; Harvell et al., 2002; Mouritsen \& Poulin, 2002) (IPPC, Intergovernmental Panel on Climate Change reports at http://www.ipcc.ch/). Temperatures and precipitations will be affected globally, regionally and locally with both increases in average values and more frequent extreme events (storms, warm events...). Among others, such changes will affect the geographical distributions of animals, plants but also their parasites, pathogen reservoirs, and vectors (Wilson, 2000; Stenseth et al., 2002; Walther et al., 2002; Lovejoy \& Hannah, 2005).

Temperature is one important abiotic parameter that may affect parasites, but also vectors, at all their life-cycle stages. Temperature impacts on the release of eggs or larvae by 
parasites and their vectors, embryonic development and hatching rates, longevity of freeliving stages, infectivity to intermediate hosts, development of either microparasites (virus, bacteria) or macroparasites (worms) in these hosts, infectivity to definitive hosts, time to maturation, and the longevity and mortality (Marcogliese, 2001; Poulin, 2006). Temperature also plays a key role in host feeding and behaviour, host range size and host resistance to infection.

Kutz et al. (2005) have shown how a host-parasite system may respond to climate change. They presented an empirical and predictive model to elucidate the impact of climate warming on development rates of a parasitic nematode of muskoxen in the Canadian Arctic, a region that is particularly vulnerable to climate change, and showed that warming in the Arctic may have already radically altered the transmission dynamics of this parasite with the number of parasite generation increasing due to the lessened detrimental effect of the outside environment. The infection pressure is then expected to continue to escalate for muskoxen.

A second example can be given by tick-borne diseases for which the tick vector is affected by climate change, such as tick-borne encephalitis (TBE) and Lyme disease. The ticks may live for several years and their survival, re-production rate and activity are affected by seasonal climate, which indirectly influences the risk of disease. Warmer temperatures increase vector and pathogen reproduction and blood feeding activity. Changes in rainfall, humidity but also large-scale meteorological phenomena such as ENSO (El Niño-Southern Oscillation) may affect the number and the quality of vector breeding sites (Liang et al., 2002). These influences may operate in synergy with other changes in the habitat and in biodiversity. Modifications of the habitat and of the occurrence of animals that are carriers of different pathogens may result in changes in the spread of tick-borne pathogens. Several studies have shown that in recent decades the tick Ixodes ricinus, transmitting Lyme borreliosis and TBE, has spread into higher latitudes and altitudes, and has become more abundant in many places (Daniel et al., 2003; Materna et al., 2005). Climate change in Europe seems likely to facilitate the spread of Lyme borreliosis and TBE into higher latitudes and altitudes, and to contribute to the extension and transmission of these diseases in some new areas. Modelling suggests that the disease will no longer persists along the southern edge of its present range but may have new foci in northern parts of Europe (Randolph, 2001).

Several other examples show that global warming has a significant impact on host-parasite interactions (McIntyre et al., 2010). However, scenarios of the future of these interactions are not easy to produce without the help of modelling. Moreover, the non-linear interactions between temperature and various aspects of parasite transmission are likely to occur and climate changes can work synergistically with other anthropogenic changes.

\subsection{Habitat fragmentation}

Escalating human activities, habitat fragmentation and degradation, and increasing the proximity between wildlife and humans have greatly impaired the health of both humans and wildlife (Daszak et al., 2000; Jones et al., 2008). These global changes are occurring at an unprecedented rate and speed, which creates opportunities for parasites to negatively affect their hosts through emergence, outbreak and higher virulence (Cleaveland et al., 2001).

Fragmentation of ecosystems, mostly due to the conversion of forests and wildlife habitats into agriculture, results in human-made island ecosystems. Knowing that true islands are 
places of high extinction rates, the fragmentation processes are likely to drive many isolated populations and species to extinction.

One potential consequence of habitat fragmentation is related to the increasing contacts among animals, both domestic and wild animals, and humans. The increasing proximity to wildlife and domestic animals results in the increased transmission of zoonotic diseases (Blouin et al., 1984; Wallis \& Lee, 1999; Daszak et al., 2000) (Table 2). For example, some

\begin{tabular}{|c|c|c|}
\hline Disease & Emergence mechanism & Anthropogenic drivers \\
\hline Malaria & niche invasion, vector expansion & deforestation, water projects \\
\hline Lymphatic filariasis & habitat alteration & water projects, urbanization \\
\hline Schistosomiasis & intermediate host expansion & water projects, irrigation \\
\hline Dengue fever & vector expansion & $\begin{array}{l}\text { Urbanization, poor housing } \\
\text { conditions }\end{array}$ \\
\hline Onchocerciasis & habitat alteration & water projects \\
\hline Chagas disease & habitat alteration & $\begin{array}{l}\text { deforestation, urban sprawl, } \\
\text { encroachment }\end{array}$ \\
\hline Leishmaniasis & vector expansion, host transfer & habitat alteration \\
\hline Meningitis & habitat alteration, dust storms & desertification \\
\hline Hantavirus & $\begin{array}{l}\text { variations in population density } \\
\text { of natural food sources }\end{array}$ & climate variability \\
\hline Rabies & $\begin{array}{l}\text { biodiversity loss, altered host } \\
\text { selection }\end{array}$ & Deforestation, mining \\
\hline Trypanosomiasis & habitat alteration & deforestation \\
\hline Encephalitis & vector expansion & irrigated rice fields \\
\hline Rift Valley fever & heavy rains & climate variability, dam building \\
\hline Lyme disease & depletion of predators & $\begin{array}{l}\text { biodiversity loss, habitat } \\
\text { fragmentation, reservoir expansion }\end{array}$ \\
\hline SARS & host transfer & $\begin{array}{l}\text { intensive livestock operations mixing } \\
\text { wild and domestic animals }\end{array}$ \\
\hline $\begin{array}{l}\text { West Nile virus and other } \\
\text { encephalitides }\end{array}$ & niche invasion & international travel, climate variability \\
\hline Cholera & sea surface temperature rising & climate variability and change \\
\hline Cryptosporidiosis & contamination by oocysts & $\begin{array}{l}\text { poor watershed management where } \\
\text { livestock exist }\end{array}$ \\
\hline Coccidioidomycosis & disturbing soils & climate variability global \\
\hline Ebola & $\begin{array}{l}\text { forest encroachment, bushmeat } \\
\text { hunting }\end{array}$ & forest encroachment \\
\hline Leptospirosis & $\begin{array}{l}\text { habitat alteration, agricultural } \\
\text { development }\end{array}$ & urban sprawl \\
\hline Nipah/Hendra viruses & niche invasion & industrial food production \\
\hline H5N1 avian influenza & $\begin{array}{l}\text { expansion of livestock } \\
\text { Production }\end{array}$ & $\begin{array}{l}\text { wild bird migration, poultry trade, } \\
\text { wild bird trade }\end{array}$ \\
\hline
\end{tabular}

Table 2. Infectious diseases, their mechanisms of emergence in relation to anthropogenic drivers (adapted from Patz \& Confalonieri, Chapter 14, MEA, 2005) (Li \& Li, 1998; Ostfeld \& Keesing, 2000; Liu et al., 2001; Fa et al., 2002; Patz et al., 2002; Brook et al., 2003; LoGiudice et al., 2003; Milner-Gulland \& Bennett, 2003; Bell et al., 2004; Foley et al., 2005; Wolfe et al., 2005; Ezenwa et al., 2006 Fergus et al., 2006; Fevre et al., 2006; Kilpatrick et al., 2006) 
management practices in national parks and natural reserves allowing or favouring multiusages, in which domestic animals graze the same lands as wild animals, facilitate the spread of diseases among them (Deem et al., 2001). Increasing encroachment of farms on wildlife habitats has also increased the overlap between livestock and wild animals, with the consequence that the vast majority of emerging diseases of livestock have been acquired from wild animals (Cleaveland et al., 2001).

The epidemiological environment is greatly altered by the recent intensification of agriculture, with massive uses of nutrients and pesticides. This may favour rodents as they are important consumers of agricultural crops. Rodents are hosts of many parasites that may cause diseases to humans, including bacteria, viral hemorrhagic fevers, tick-borne encephalites, but also macroparasites such as trematodoses and nematodoses (Meerbur et al., 2009). Agricultural intensification favours rodent outbreaks through the removal of predators and other natural enemies, while supplementing their food supply, with subsequent disease outbreaks in rural human populations (Chaisiri et al., 2010).

In many Western countries the epidemiological environment is significantly altered by reforestation and suburbanization. These changes in land uses may have consequences for humans and their domestic animals by increasing the contact between wild animals, and in particular rodents. A good example of this is given by Lyme disease, which has spread over the last decades due to increases in deer populations, and also rodent and tick populations, human recreational activities and contacts with ticks (see Daily \& Ehrlich, 1996).

Disturbance seems to favour generalist hosts, i.e. hosts that are able to use different types of habitats (Marvier et al., 2004). These generalist hosts often have a broad geographical distribution and a high resilient ecology (Smart et al., 2006), two potential determinants for hosting high diversified parasite communities (see above). These species seem also to have higher reservoir or vector competence than species that are not favoured by disturbance (Mills, 2006; Vittor et al., 2006; Molyneux et al., 2008; Chaisiri et al., 2010). Moreover, these species being released for competitors may rich high population density.

\subsection{Biological invasion and parasite release}

Parasites are linked to biological invasions either as invader, often through the help of carriers, or by facilitating the invasion success of their hosts. The worldwide introduction of parasites, infectious diseases and their vectors and carriers is linked to globalization, international trades and increasing human travels. The introduction of the mosquito Aedes albopictus in many parts of the world has facilitated the transmission of the Chikungunya virus (Benedict et al., 2007; Charrel et al., 2007).

Less known are the indirect effects of parasitism and the success of biological invaders. The "parasite release hypothesis" has been proposed as an ecological mechanism to explain the success of introduced or invasive species, as they often lose their parasites when invading new habitats. Introduced species have a competitive advantage over local species because they are released from control by their natural enemies. Mitchell \& Power (2003) and Torchin et al. (2003) found that parasitism is significantly reduced in organisms in their introduced range, supporting this hypothesis. The parasite release hypothesis may then explain the success of introduced species and the demographic explosion of some introduced species (Clay, 2003; Keane \& Crawley, 2003; Mitchell \& Power, 2003; Torchin et al. 2003). 


\subsection{Extinction}

Pathogens are considered to be a serious threat in conservation biology (Daszak \& Cunningham, 1999; Daszak et al., 2000; Cleaveland et al., 2001). Pathogens have been implicated in the extinction of numerous species (McCallum \& Dobson, 1995; Vitousek et al., 1997), such as several endemic Hawaiian birds (VanRiper et al., 1986, 2002) or the thylacine (an Australian marsupial carnivore). Daszak et al. (2000) mentioned 19 parasites as important dangers for conservation or for human health (major zoonotic agents). Theoretically, several mechanisms can produce extinction due to parasitism (Table 3):

\begin{tabular}{|l|l|l|l|}
\hline Mechanism & Host species & Pathogen / Impact & References \\
\hline $\begin{array}{l}\text { Small population } \\
\text { syndrome }\end{array}$ & $\begin{array}{l}\text { Thylacine (Thylacinus } \\
\text { cynocephalus) }\end{array}$ & $\begin{array}{l}\text { Virus/probable } \\
\text { extinction }\end{array}$ & $\begin{array}{l}\text { Guiler, 1961 (in } \\
\text { McCallum \& Dobson, } \\
1995)\end{array}$ \\
\cline { 2 - 4 } & $\begin{array}{l}\text { Random Golden toad } \\
\text { (Bufo periglenes) }\end{array}$ & $\begin{array}{l}\text { Virus/probable } \\
\text { extinction }\end{array}$ & Pounds et al. (1997) \\
\cline { 2 - 5 } & $\begin{array}{l}\text { Black-footed ferret } \\
\text { (Mustela nigripes) }\end{array}$ & $\begin{array}{l}\text { Virus/probable } \\
\text { extinction }\end{array}$ & $\begin{array}{l}\text { Thorne \& Williams } \\
(1988)\end{array}$ \\
\hline $\begin{array}{l}\text { Feral goats (Capra } \\
\text { pyrenaica hispanica) }\end{array}$ & $\begin{array}{l}\text { Mite/reduction in } \\
\text { population size }\end{array}$ & $\begin{array}{l}\text { Leon-Vizcaino et al. } \\
\text { (1999) }\end{array}$ \\
\hline $\begin{array}{l}\text { Reduced genetic } \\
\text { variability }\end{array}$ & $\begin{array}{l}\text { Cheetah (Acinonyx } \\
\text { jubatus) }\end{array}$ & $\begin{array}{l}\text { Virus/increased } \\
\text { susceptibility to } \\
\text { diseases }\end{array}$ & O'Brien et al. (1985) \\
\hline $\begin{array}{l}\text { Independent } \\
\text { transmission }\end{array}$ & $\begin{array}{l}\text { Rabbit (Oryctolagus } \\
\text { cuniculus) }\end{array}$ & $\begin{array}{l}\text { Virus/haemorrhagic } \\
\text { disease, potential } \\
\text { extinction (model) }\end{array}$ & White et al. (2003) \\
\hline Reservoir & $\begin{array}{l}\text { White-tailed deer } \\
\text { (Odocoileus virginianus) } \\
\text { elk (Alces alces) }\end{array}$ & $\begin{array}{l}\text { Nematode/reduction } \\
\text { in population size }\end{array}$ & $\begin{array}{l}\text { Schmitz \& Nudds } \\
\text { (1994) }\end{array}$ \\
\cline { 2 - 4 } $\begin{array}{l}\text { Grey squirrel (Sciurus } \\
\text { carolinensis), red squirrel } \\
\text { (Sciurus vulgaris) }\end{array}$ & $\begin{array}{l}\text { Virus/reduction in } \\
\text { population size }\end{array}$ & Rushton et al. (2000) \\
\hline
\end{tabular}

Table 3. Several examples of a proven or potential role for parasitism in extinction of the host population (modified from Gog et al., 2002)

1. Small population syndrome.

Small populations are characterized by low densities, which are reduced in the presence of a pathogen. Fluctuations below a persistence threshold can increase and proceed to extinction because of random environmental processes. The impact of parasites can also drive the host population close to the threshold for the Allee effect (the threshold below which the population inexorably declines), leading the host population into a spiral to extinction (Deredec \& Courchamp, 2003).

2. Reduced genetic variability.

Small populations are often characterized by a high degree of relatedness, with a reduced genetic variability, especially for genes involved in resistance against parasites such as major histocompatibility complex (MHC) genes. 
3. Density-independent or vector-transmitted parasites.

Sexually or vector- transmitted parasites show a transmission independent of host population size because of the dilution effect (i.e. transmission is density independent). Then, regulatory effects are maintained or may increase with a reduction in the host population.

4. Reservoir effect and apparent competition.

Non-specific parasites are maintained on abundant populations but continue regulating all populations, even small ones.

\section{How biodiversity is related to the emergence of infectious diseases}

Diseases are now considered as important factors in the conservation of biodiversity (Meffe, 1999; Daszak et al., 2000; Deem et al., 2001). Several reviews have emphasized the potential impact of parasites and pathogens on their host population dynamics under global changes. Several studies have also emphasized the need to preserve vertebrate biodiversity and community composition in order to significantly reduce the risk of emergence (LoGiudice et al., 2003; Keesing et al., 2010). In a recent review, Keesing et al. (2010) have given some examples of the impacts of biodiversity changes on diseases (Table 4).

\begin{tabular}{|c|c|c|}
\hline Diseases & Mechanism & References \\
\hline \begin{tabular}{|l} 
Bacteriophage of \\
Pseudomonas syringae
\end{tabular} & host/vector/parasite behaviour & Dennehy et al. (2007) \\
\hline Coral diseases & host/vector abundance & Raymundo et al. (2009) \\
\hline Fungal disease of Daphnia & host/vector/parasite behaviour & Hall et al. (2009) \\
\hline Hantavirus disease & $\begin{array}{l}\text { host/vector abundance, } \\
\text { host/vector/parasite behaviour }\end{array}$ & $\begin{array}{l}\text { Tersago et al. (2008); Clay et } \\
\text { al. (2009); Dizney \& Ruedas } \\
\text { (2009); Suzan et al. (2009) }\end{array}$ \\
\hline Helminthic parasite of fish & host/vector abundance & Kelly et al. (2009) \\
\hline Lyme disease & $\begin{array}{l}\text { host/vector abundance, } \\
\text { host/vector/parasite behaviour }\end{array}$ & $\begin{array}{l}\text { Brunner \& Ostfeld (2008); } \\
\text { LoGiudice et al. (2008), } \\
\text { Keesing et al. (2009) }\end{array}$ \\
\hline Malaria & host/vector abundance & Carlson et al. (2009) \\
\hline Schistosomiasis & host/vector/parasite behaviour & Johnson et al. (2009) \\
\hline $\begin{array}{l}\text { Trematode diseases of snails } \\
\text { and birds }\end{array}$ & host/vector/parasite behaviour & $\begin{array}{l}\text { Kopp \& Jokela (2007); } \\
\text { Thieltges et al. }(2008,2009)\end{array}$ \\
\hline West Nile fever & $\begin{array}{l}\text { host/vector abundance } \\
\text { host/vector/parasite behaviour }\end{array}$ & $\begin{array}{l}\text { Ezenwa et al. (2006); } \\
\text { Swaddle \& Calos (2008); } \\
\text { Allan et al. (2009); Koenig } \\
\text { et al. (2010) }\end{array}$ \\
\hline
\end{tabular}

Table 4. Biodiversity loss and increase disease transmission (adapted from Keesing et al., 2010)

Anthropogenic drivers of global change affect biodiversity (through climate change, habitat fragmentation, land-use changes and bioinvasions). Changes at all levels in biodiversity (genetic, population and community) affect ecosystem functioning and, in particular, hostpathogen interactions, with major consequences in health ecology (emergence and reemergence, outbreaks) (Fig. 3). 
Any change in species richness may affect the dynamics of infectious diseases with potential increase or decrease in parasite transmission:

1. Dilution effect.

The dilution effect refers to describe a pattern when increased species diversity reduces disease risk. The processes may be linked to a variety of mechanisms (Keesing et al., 2006). This applies to vector-borne and directly transmitted diseases, although the concept of dilution has been developed most with regards to the tick-borne Lyme disease (Allan et al., 2003; LoGiudice et al., 2003, 2008).

The hypothesis underlying the dilution effect is that for many diseases, the competence of reservoirs, i.e. the ability to become infected and retransmit the pathogen, varies according to the host species (Haydon et al., 2002). The composition of the host community thus can influence the transmission dynamic of the disease. Similarly, since vectors have different competence to transmit pathogens, the composition of the vector community may also likely influence transmission dynamics. Different mechanisms are thought to be involved, but they are difficult to differentiate (Keesing et al., 2006; Begon, 2008). One is the modification of the encounter rate (when reduced, this corresponds to a real "dilution effect"). In the presence of species that are poorly or not competent, the infectious agent may be transmitted to a non-competent individual rather than to a susceptible individual. For vector-borne diseases, the increased species diversity of poorly competent hosts on which the vector feeds increases the proportion of vector bites that are wasted for the parasite transmission (Table 3). For direct transmission, the addition of non competent hosts can decrease transmission if these hosts remove infective stages (Begon, 2008).

Another mechanism at work is that high host species diversity regulates the abundance of the competent host population. This regulation can be mediated by interspecific competition for limiting resources or by predation upon competent hosts. It could also mediated by parasite interactions through apparent competition. By decreasing densities of competent hosts, high biodiversity modulates the parasite population dynamics.

The potential link between parasitism and the interaction between predators and the diversity of preys may also be involved. This may happen when predators modify the mortality rate of a host and lower pathogen transmission by feeding on a heavily diseased individual (Packer et al., 2003).

The dilution effect has been demonstrated through theoretical works and empirically observed in several host-parasite systems (Table 3). One example is Lyme disease in the USA that is caused by pathogenic bacteria transmitted by ticks. These ticks feed readily on many species of vertebrates and these species vary in their degrees of reservoir competence. The white-footed mouse (Peromyscus leucopus) is thought to be the most competent host and dominates in fragmented forests. In native forests, which harbour a higher diversity of species than fragmented forests, ticks have a higher probability to dilute their bites by feeding on less competent hosts (Allan et al., 2003; LoGiudice et al., 2003, 2008). Another example is the West Nile virus. Increased species diversity of on passerine birds, which are less competent reservoir hosts compared to passerines, was found associated with decreased West Nile virus infection in mosquitoes and humans (Ezenwa et al. 2006, Swaddle \& Calos 2008).

There have been few examples of directly transmitted diseases, but studies on hantaviruses and rodents have shown that higher diversity of these small mammals appears to regulate reservoir host populations through competition or predation with the net consequence to 
decrease hantavirus transmission. High rodent species richness might also inhibit intraspecific aggressive encounters between reservoir hosts that result in hantavirus transmission (Suzán et al., 2009).

2. Amplification effect.

Amplification effects are typically associated with the consequences of species introduction that radically modifies encounter rates. The introduced species can introduce new pathogens that may infect native hosts (i.e. spillover) (Bruemmer et al., 2010). But the introduced species can amplify the circulation of local pathogens (i.e. spillback) (Kelly et al., 2009), although the introduction of a resistant host may favour dilution (Kopp \& Jokela, 2007). The introduction of additional species as providing new hosts for vectors may increase vector numbers or their activities (Saul, 2003). For example, the introduced Siberian chipmunks (Tamias sibiricus) in suburban forests increase the risk of Lyme disease because of its higher competence in regard to native hosts (Vourc'h et al., 2007).

\section{How biodiversity sciences may contribute to health}

\subsection{Predicting bioinvasions}

Biotic invaders are species that establish in a new area in which they proliferate to the detriment of local species and the environment. They are the biggest ecological outcomes of the global alterations and distributions of the earth's biota due to human transport and commerce (Williamson, 1996). As emphasized by Mack et al. (2000), biotic invasions can be compared with epidemics because many important factors in disease epidemiology are common to invasions. These factors are the minimum population size necessary for successful establishment, population growth and the fate of interacting species in the new range.

The movement of parasites, potential vectors, or disease reservoirs is greatly facilitated by intense modern transport. A recent case of transfer of a dangerous vector was the introduction from Asia to the United States and several European countries of a mosquito (Aedes albopictus) capable of transmitting dengue (Scholte \& Schaffner, 2007).

Identifying future parasite or vector invaders and vulnerable communities, and taking effective measures to prevent their establishment and their dispersal, are great challenges for conservation biology and ecological health. The features associated with bio-invasions are:

1. Attributes of parasite invaders.

Parasite invaders are generally those parasites that are found in high local abundances or prevalences, with direct life-cycles and low host specificity. Local abundances of a parasite species are positively correlated with their geographical distribution, with highly abundant parasites found in a larger number of host populations. The distribution of parasites with indirect life-cycles is dependent on those of all hosts in the life cycle. Any modification of host distribution will determine if parasites can persist and where they colonize (Dobson \& Carper, 1992). Nevertheless, parasites that have indirect life-cycles such as Schistosoma mansoni, Fasciola hepatica or Angiostrongylus spp. can be invaders. Low host specificity may not always be a crucial characteristic of parasite invaders, a more important characteristic being the ability of the parasite to switch host. 
2. Attributes of invading hosts, vectors and reservoirs.

Many morphological and ecological characteristics may favour invasion success. The introduced species may have a competitive advantage over local species because in the new area they are released from control by their natural enemies. Mitchell \& Power (2003) and Torchin et al. (2003) showed that parasite diversity is significantly reduced in organisms in their introduced range compared to their native range, supporting the "parasite release hypothesis".

Invasive hosts are also at an advantage during concomitant invasion when they have evolved strong immune defences in their original range. High immune investment confers a better capacity to control parasites that they may acquire or be in contact with in the introduced range (Lee \& Klasing, 2004; Møller \& Cassey, 2004).

3. Community vulnerability.

Vacant niches within communities, i.e. low species richness, both in hosts and in their parasites is widely assumed to provide opportunities for the settlement and spread of biotic invaders (Elton, 1958). The vacant niches hypothesis suggests that species-poor communities cannot offer biological resistance to invasion and particularly to pathogen or vector invasion.

\subsection{Predicting extinctions}

Climate changes, but also habitat uses' changes, will extend the geographical ranges of many species along with their parasites, potentially overlapping with endangered species and driving them to extinction (Dobson \& Carper, 1992). The seasonal and spatial distributions of parasites and their hosts are often temperature dependent and the synchronicity of their population dynamics is threatened by climatic changes. Many parasites have adapted their life cycles, reproduction, and transmission to overlap with definitive and intermediate hosts (Poulin, 2006; see above Kutz et al., 2005). Any increase in temporal asynchrony between infective parasite stages and hosts has significant effects on the persistence of the interaction. Some parasites will adapt to these new conditions, whereas others may not. We may expect parasite extinctions to occur.

The global extinction of parasites may be more pronounced than that of free-living animals. According to Poulin \& Morand (2004), the $11 \%$ of threatened mammalian species imply that a total of 409 helminth species are at risk of extinction. This predicted parasite extinction may also have consequences on the epidemiological environment.

\subsection{Predicting distribution using modeling environmental niche}

Ecological niche modelling is used in biogeography to predict the distributional range of species from existing occurrence data (Anderson et al., 2003). Using appropriate algorithms in a GIS containing layers of environmental information (such as topography, climate, and vegetation), epidemiological and spatial risk stratification can be achieved from data on the location of vectors or pathogens. This approach has been used in the case of Chagas disease and for vectors of leishmaniasis and filovirus infections (Peterson et al., 2002, 2004a,b). Moreover, using scenarios of climate change, it is then possible to project scenarios of pathogen and vector distribution changes.

\subsection{The importance of preserving parasite diversity}

Parasite extinction may count. Hence, for any host extinction, at least one parasite may go with it (Poulin \& Morand, 2004). This may not be seen as a positive consequence as parasites 
should not only be thought of as harmful, however. Parasites have their own intrinsic value (Sprent, 1992). They contribute to maintain high diversity as ecological engineers (Thomas et al., 1999), they may control biotic invaders, and they stabilize ecosystems (Marcogliese \& Cone, 1997; Mouritsen et al., 2005; Arias-González \& Morand, 2006; Pedersen \& Fenton, 2006). At the individual host level, parasites may help to equilibrate immune responses and prevent the spread of other parasites. There is then a balance between the need to control parasites and the benefits of their presence (Pedersen \& Fenton, 2006).

\section{Ecosystem services, biodiversity and health}

Variability among ecosystems is a key element of biodiversity. Climate changes, land-use changes, the over-use of living resources and bioinvasion all affect biodiversity, not only by increasing species loss but also by potentially damaging the functioning of ecosystems. Theoretical and empirical works have both identified links between global changes, biodiversity and the way in which ecosystems function (Chapin et al., 2000).

\section{Anthropogenic drivers of global change}
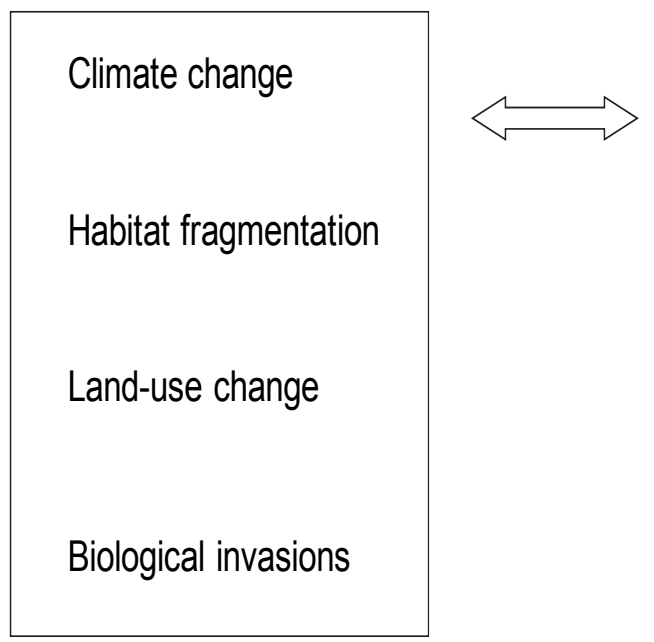

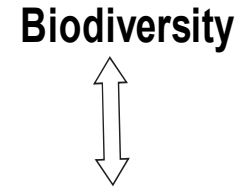

Ecosystem functioning

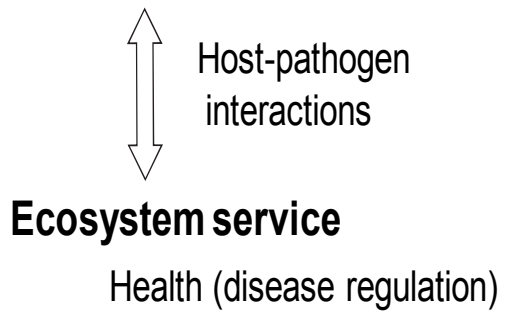

Fig. 3. Anthropogenic drivers of global change may affect biodiversity (climate change, habitat fragmentation, land-use changes, and bioinvasions). Changes at all levels of biodiversity (from genes to ecosystems) affect ecosystem functioning with major consequences in health ecology (emergence and re-emergence, the evolution of virulence and resistance). All theses impact the services providing by ecosystems, such as disease regulation, with a potential effect on human well-being

The Millennium Ecosystem Assessment was initiated in 2001. Its objectives were to assess the consequences of ecosystem change for human well-being and to provide the scientific basis for the actions needed to enhance conservation and sustainable use. More than 1,360 experts throughout the world worked on this project, with the goals of examining the present condition and future trends of the ecosystems of the world, assessing the services 
that such ecosystems provide, and developing solutions to enhance the sustainable use of these ecosystems.

Among the benefits obtained by humans from the regulation of ecosystem processes are the regulation of human and animal diseases (since any changes in ecosystems can directly affect human pathogens or disease vectors, such as mosquitoes), and biological control (since any changes can affect crop pests and plant diseases). One important concept has emerged from the ecosystem approach, the idea of 'ecosystem health'. This term is often applied in the evaluation of ecosystems, although it is also used to refer to the links between ecosystems and human (and animal) health, by emphasising the regulating role of ecosystems on pathogens.

The next step was to develop biodiversity indicators. Twenty-two biodiversity indicators have been developed by the international organisations which participated in the 2010 Biodiversity Indicators Partnership (www.twentyten.net). However, the development of these indicators has recently been found to be incomplete. Moreover, these indicators do not include any measure of the impact of climate change on biodiversity, and few may be used to estimate the goods and services that people gain from biodiversity and ecosystems (Walpole et al., 2010).

\section{Conclusion}

Several studies now recognize the need to preserve biodiversity in order to maintain high ecological health (Aguirre et al., 2002). This task needs to be given a higher priority and increase its rate of discovery, in particular by collecting data, and organizing databases on parasites and their hosts (Brooks \& Hoberg, 2000).

Finally, as a conclusion, we aim at emphasizing that biodiversity sciences, ecology and evolution, are central to the study of zoonotic diseases in relation to climate changes. We should aware that if climate, and its variability, by itself is important as a key factor in pathogen transmission, this factor works in synergy with other drivers of the global changes such as land-use changes, habitat fragmentation and bioinvasion. Anthropogenic drivers of global change affect biodiversity, including parasite biodiversity, potentially modifying the epidemiological environment (Daily \& Ehrlich, 1996).

Increasing collaboration between biodiversity scientists and the health sciences corresponds to the call of scientific expertises conducted by IPCC, MEA, IPBES (" Intergovernmental Science-Policy Platform on Biodiversity and Ecosystem Services»), and other international agencies, such as FAO, OIE, and WHO. The "One Health" approach is one initiative that points out the need to modify disease control strategies. The current approach to disease prevention and control emphasizes transmission disruption (early warning, early detection and early response mechanisms targeting), while the new approach promoted by the "One Health" is to act at the driver level of diseases, i.e. at the human-animal-ecosystems interface (Burgos \& Slingenbergh, 2011).

\section{Acknowledgment}

The author thanks Dr. Jordi López-Pujol, editor of this book, for his kind invitation. The author also thanks the ANR CERoPath (ANR 07 BDIV 012). 


\section{References}

Aguirre, A.A.; Ostfeld, R.S.; House, C.A.; Pearl, M.A. \& Tabor, G.M. (2002). Conservation medicine: Ecological health in practice. Oxford University Press, Oxford

Altizer, S.: Nunn, C.L.; Thrall, P.H; Gittleman, J.L.; Antonovics, J. et al. (2003). Social organization and parasite risk in mammals: integrating theory and empirical studies. Annual Review of Ecology and Systematics, Vol.34, pp. 517-547

Allan; B.F.; Keesing, F. \& Ostfeld, R.S. (2003). Effect of forest fragmentation on Lyme disease risk. Conservation Biology, Vol.17, pp. 267-272.

Allan, B.F.; Langerhans, R.B.; Ryberg, W.A.; Landesman, W.J.; Griffin, N.W. et al. (2009). Ecological correlates of risk and incidence of West Nile virus in the United States. Oecologia, Vol.155, pp. 699-708.

Anderson, R.P.; Lew, D. \& Peterson, A.T. (2003). Evaluating predictive models of species' distributions: criteria for selecting optimal models. Ecological Modelling, Vol.162, 211-232.

Arias-González, J.E. \& Morand, S. (2006). Trophic functioning with parasites: a new insight for ecosystem analysis. Marine Ecology Progress Series, Vol.320, 43-53.

Arneberg, P. (2002). Host population density and body mass as determinants of species richness in parasite communities: comparative analyses of directly transmitted nematodes of mammals. Ecography, Vol.25, 88-94.

Arneberg, P.; Skorping, A.; Grenfell, B. \& Read, A. F. (1998). Hosts densities as determinants of abundance in parasite communities. Proceedings of the Royal Society B-Biological Sciences, Vol.266: 1283-1289.

Begon, M. (2008). Effect of host diversity on disease dynamics, In: Effects of Ecosystems on Disease and of Disease on Ecosystems, R.S. Ostfeld, F. Keesing \& Eviner V.T. (Eds.), 1229, Princeton University Press, Princeton.

Bell, D.; Roberton, S. \& Hunter, P. R. (2004). Animal origins of SARS coronavirus: possible links with the international trade in small carnivores. Philosophical Transactions of the Royal Society of London B Biological Sciences, Vol.359, 1107-1114.

Benedict, M.Q.; Levine, R.S.; Hawley, W.A. \& Philipp Lounibos, L. (2007). Spread of the tiger: Global risk of invasion by the mosquito Aedes albopictus. Vector-Borne and Zoonotic Diseases, Vol.7, 76-85.

Bordes, F.; Blumstein, D.T. \& Morand, S. (2007). Rodent sociality and parasite diversity. Biology Letters, Vol.3: 692-694.

Bordes, F.; Guégan, J.F.; Morand, S. (2011). Microparasite species richness in rodents is higher at lower latitudes and is associated with reduced litter size. Oikos (in press)

Bordes F.; Morand, S.; Kelt, D.A. \& Van Vuren, D.H. (2009). Home range and parasite diversity in mammals. The American Naturalist, Vol.173, 467-474

Bordes, F.; Morand, S.; Krasnov, B.R. \& Poulin, R (2010). Parasite diversity and latitudinal gradients in terrestrial mammals. In: The Biogeography of Host-Parasite Interactions, S. Morand \& B.R. Krasnov (Eds), 89-98, Oxford University Press.

Brooks, D.R. \& Hoberg, E.P. (2000). Triage for the biosphere: The need and rationale for taxonomic inventories and phylogenetic studies of parasites. Comparative Parasitology, Vol.67, 1-25.

Bruemmer, C. M., Rushton, S. P., Gurnell, J., Lurz, P. W., Nettleton, P. et al. (2010). Epidemiology of squirrelpox virus in grey squirrels in the UK. Epidemiology and Infection, Vol.138, 941-950.

Brunner, J. \& Ostfeld, R.S. (2008). Multiple causes of variable tick burdens on small mammal hosts. Ecology, Vol.89, 2259-2272. 
Burgos, S. \& Slingenbergh, J. (2011). Thoughts on human-animal-ecosystems interface. Transboundary and Emerging Diseases, on line version, doi:10.1111/j.18651682.2011.01214.x

Chaisiri, K.; Chaeychomsri, W.; Siruntawineti, J.; Bordes, F.; Herbreteau, V. \& Morand, S. (2010). Human-dominated habitats and helminth parasitism in Southeast Asian murids. Parasitology Research, Vol.107, 931-937.

Carlson, J.C.; Dyer, L.A., Omlin, F.X. \& Beier, J.C. (2009). Diversity cascades and malaria vectors. Journal of Medical Entomology, Vol.46, 460-464.

Charrel, R.N.; de Lamballerie, X.; Raoult. D. (2007). Chikungunya outbreaks - The globalization of vectorborne diseases. New England Journal of Medicine, Vol.356, 769771.

Chapin, F.S. III; Zaveleta, E.S.; Eviner, V.T.; Naylor, R.L.; Vitousek, P.M.; Lavorel, S.; Reynolds, H.L.; Hooper, D.U. et al. (2000). Consequences of changing biotic diversity. Nature, Vol.405, 234-242

Chivian, E. \& Bernstein, A.S. (2004). Embedded in nature: human health and biodiversity. Environmental Health Perspectives, Vol.112, 12-13.

Clay, C.; Lehmer, E.M.St.; Jeor, S. \& Dearing, M.D. (2009). Sin Nombre virus and rodent species diversity: a test of the dilution and amplification hypotheses. PLoS ONE, Vol.4, e6467.

Clay, K. (2003). Parasites lost. Nature, Vol.421, 585-586.

Cleaveland, S.; Laurenson, M.K. \& Taylor, L.H. (2001). Diseases of humans and their domestic mammals: Pathogen characteristics, host range and the risk of emergence. Philosophical Transactions of the Royal Society London B, Vol.356, 991-999.

Daily, G.C. \& Ehrlich, P.R. (1996). Global change and human susceptibility to disease. Annual Review of Energy and Environment, Vol.21, 125-144.

Daniel, M.; Danielova, V.; Kriz, B.; Jirsa, A. \& Nozicka, J. (2003). Shift of the tick Ixodes ricinus and tick-borne encephalitis to higher altitudes in central Europe. European Journal of Clinical Microbiology Infectious Diseases, Vol.22, 327-328.

Daszak, P. \& Cunningham, A.A. (1999). Extinction by infection. Trends in Ecology and Evolution, Vol.14, 279.

Daszak, P., Cunningham, A.A. \& Hyatt A.D. (2000). Emerging infectious diseases of wildlife: threats to biodiversity and human health. Science, Vol.287, 433-449.

Deem, S.L., Karesh, W.B. \& Weisman, W. (2001). Putting theory into practice: Wildlife health in conservation. Conservation Biology, Vol.15, 1224-1233.

Dennehy, J.J., Friedenberg, N.A., Yang, Y.W. \& Turner, P.E. (2007). Virus population extinction via ecological traps. Ecology Letters, Vol.10, 230-240.

Deredec, A., Courchamp, F. (2003). Extinction thresholds in host-parasite dynamics. Annales Zoologi Fennici, Vol. 40: 115-130.

Dizney, L.J. \& Ruedas, L.A. (2009). Increased host species diversity and decreased prevalence of Sin Nombre virus. Emerging Infectious Diseases, Vol.15, 1012-1018.

Dobson, A.P. \& Carper, R. (1992). Global warming and potential changes in host-parasite and disease-vector relationships. In: Global warming and biological diversity, R.L. Peters \& T.E. Lovejoy (Eds), 201-217, Yale Univ Press, New Haven.

Dunn, R.R.; Davies, T.J.; Harris, N.C., \& Gavin, M.C. (2010). Global drivers of human pathogen richness and prevalence. Proceedings of the Royal Society B-Biological Sciences, Vol.277, 2587-2595.

Elton, C.S. (1958). The ecology of invasions by animals and plants. Methuen, London. 
Ezenwa, V., Price, S.A.; Altizer, S.; Vitone, N.D. \& Cook, C. (2006). Host traits and parasite species richness in even- and odd-toed hoofed mammals, Artiodactyla and Perissodactyla. Oikos, Vol.115, 526-537.

Ezenwa, V.O., Godsey, M.S., King, R.J. \& Guptill1, S.C. (2006). Avian diversity and West Nile virus: testing associations between biodiversity and infectious disease risk. Proceedings of the Royal Society B-Biological Sciences, Vol.273, 109-117.

Feliu, C.; Renaud, F.; Catzeflis, F.; Durand, P.; Hugot, J.-P. \& Morand, S. (1997). A comparative analysis of parasite species richness of Iberian rodents. Parasitology, Vol.115, 453-466.

Fergus, R.; Fry, M.; Karesh, W.B.; Marra, P. P.; Newman, S. \& Paul, E. (2006). Migratory birds and avian flu. Science, Vol.312:845-846.

Fevre, E.M.; Bronsvoort, B.; Hamilton, K.A. \& Cleaveland, S. (2006). Animal movements and the spread of infectious diseases. Trends in Microbiology, Vol.14, 125-131.

Foley, J. A.; DeFries, R.; Asner, G. P.; Barford, C.; Bonan, G. et al. (2005). Global consequences of land use. Science, Vol.309, 570-574.

Gog, J.; Woodroffe, R. \& Swinton, J. (2002). Disease in endangered metapopulations: the importance of alternative hosts. Proceedings of the Royal Society B: Biological Sciences, Vol.269: 671-676.

Goüy de Bellocq, J.; Charbonnel, N. \& Morand, S. (2008). Coevolutionary relationship between helminth diversity and MHC class II polymorphism in rodents. Journal of Evolutionary Biology, Vol.21, 1144-1150

Guernier, V.; Hochberg, M.E. \& Guégan, J.F. (2004). Ecology drives the worldwide distribution of human infectious diseases. PloS Biology, Vol.2: 740-46.

Hall, S.R.; Becker, C.R.; Simonis, J.L.; Duffy, M.A., Tessier, A.J. et al. (2009). Friendly competition: evidence for a dilution effect among competitors in a planktonic hostparasite system. Ecology, Vol.90, 791-801.

Harvell, C.D.; Mitchell, C.E.; Ward, J.R.; Altizer, S.; Dobson, A.P.; Ostfeld, R.S. \& Samuel M.D. (2002). Climate warming and disease risks for terrestrial and marine biota. Science, Vol.296, 2158-2162.

Haydon, D.T.; Cleaveland, S.; Taylor, L.H. \& Laurenson, M.K. (2002). Identifying reservoirs of infection: a conceptual and practical challenge. Emerging Infectious Diseases, Vol.8, 1468-1473.

Jones, K.E.; Patel, N.G.; Levy, M.A., Storeygard, A.; Balk, D. et al. (2008). Global trends in emerging infectious diseases. Nature, Vol.451, 990-993.

Johnson, P. T. J.; Lund, P.; Hartson, R.B .\& Yoshino, T. (2009). Community diversity reduces Schistosoma mansoni transmission and human infection risk. Proceedings of the Royal Society B-Biological Sciences, Vol.276, 1657-1663.

Keane, R.M. \& Crawley, M.J. (2002). Exotic plant invasions and the enemy release hypothesis. Trends in Ecology and Evolution, Vol.17, 164-179.

Keesing, F.; Brunner, J., Duerr, S.; Killilea, M.; LoGiudice, K. et al. (2009). Hosts as ecological traps for the vector of Lyme disease. Proceedings of the Royal Society B-Biological Sciences, Vol.276, 3911-3919.

Keesing, F.; Belden, L.K.; Daszak, P.; Dobson, A.; Harvell, C.D. et al. (2010). Impacts of biodiversity on the emergence and transmission of infectious diseases. Nature, Vol.468, 647-652.

Keesing, F.; Holt, R.D. \& Ostfeld, R.S. (2006). Effects of species diversity on disease risk. Ecology Letters, Vol.9, 485-498.

Kelly, D.W.; Paterson, R.A.; Townsend, C.R.; Poulin, R. \& Tompkins, D. M (2009). Parasite spillback: a neglected concept in invasion ecology? Ecology, Vol.90, 2047-2056. 
Kelly, D.W., Paterson, R.A., Townsend, C.R., Poulin, R. \& Tompkins, D.M. (2009). Has the introduction of brown trout altered disease patterns in native New Zealand fish? Freshwater Biology, Vol.54, 1805-1818.

Kilpatrick, A.M.; Kramer, L. D.; Jones, M. J.; Marra, P. P. \& Daszak, P. (2006). West Nile virus epidemics in North America are driven by shifts in mosquito feeding behavior. Plos Biology, Vol.4, 606-610.

Koenig, W.D., Hochachka, W.M., Zuckerberg, B. \& Dickinson, J.L. (2010) Ecological determinants of American crow mortality due to West Nile virus during its North American sweep. Oecologia, Vol.163, 903-909.

Kopp, K. \& Jokela, J. (2007). Resistant invaders can convey benefits to native species. Oikos, Vol. 116, 295-301.

Kovats, R.S.; Campbell-Lendrum, D.H.; McMichael, A.J.; Woodward, A. \& Cox, J.S.H. (2001). Early effects of climate change: Do they include changes in vector-borne disease? Proceedings of the Royal Society London B, Vol.356, 1057-1068.

Krasnov, B.R; Shenbrot, G.I.; Khokhlova, I. \& Degen, A.A. (2004). Flea species richness and parameters of host body, host geography and host "milieu". Journal of Animal Ecology, Vol.73: 1121-1128.

Kutz, S.J.; Hoberg, E.P.; Polley, L. \& Jenkins, E.J. (2005). Global warming is changing the dynamics of Arctic host-parasite systems. Proceedings of the Royal Society London B, Vol.272, 2571-2954.

Lee, K.A. \& Klasing, K.C. (2004). A role for immunology in invasion biology. Trends in Ecology and Evolution, Vol.19, 523-529.

Leon-Vizcaino, L.; de Ybanez, M.R.R.; Cubero, M.J.; Ortiz, J.M.; Espinosa, J. et al. (1999). Sarcoptic mange in Spanish ibex from Spain. Journal of Wildlife Diseases, Vol.35, 647659.

Li, Y.M. \& Li, D.M. (1998). The dynamics of trade in live wildlife across the Guangxi border between China and Vietnam during 1993-1996 and its control strategies. Biodiversity and Conservation, Vol.7, 895-914.

Liang, S.Y.; Linthicum, K.J. \& Gaydos, J.C. (2002). Climate change and the monitoring of vector-borne disease. Journal of the American Medical Association, Vol.287, 2286.

Lindenfors, P.; Nunn, C.L.; Jones, K.E.; Cunningham, A.A.; Sechrest, W. \& Gittleman, J.L. (2007). Parasite species richness in carnivores: effects of host body mass, latitude, geographical range and population density. Global Ecology and Biogeography, Vol.1: $1-14$.

Liu, J.G.; Linderman, M.; Ouyang, Z.Y.; An, L.; Yang, J. \& Zhang, H.M. (2001). Ecological degradation in protected areas: The case of Wolong Nature Reserve for giant pandas. Science, Vol.292, 98-101.

LoGiudice, K.; Duerr, S.T.K.; Newhouse, M.J.; Schmidt, K.A.; Killilea, M.E. \& Ostfeld, R.S. (2008) Impact of host community composition on Lyme disease risk. Ecology, Vol.89, 2841-2849.

LoGiudice, K., Ostfeld, R.S., Schmidt, K.A. \& Keesing, F. (2003). The ecology of infectious disease: Effects of host diversity and community composition on Lyme disease risk. Proceedings National Academy of Sciences USA, Vol.100, 567-571.

Lovejoy, T.E. \& Hannah, L. (2005). Climate change and biodiversity. Yale Univ Press, New Heaven.

Mack, R.N.; Simberloff, D.; Lonsdale, W.M.; Evans, H.; Clout, M. \& Bazzaz, F.A. (2000). Biotic invasions: Causes, epidemiology, global consequences, and control. Ecological Applications, Vol.10, 689-710. 
Marcogliese, D.J. (2001). Implications of climate change for parasitism of animals in the aquatic environment. Canadian Journal of Zoology, Vol.79, 1331-1352.

Marcogliese, D.J. \& Cone, D.K. (1997). Food webs: A plea for parasites. Trends in Ecology and Evolution, Vol.12, 320-325.

Marvier, M.; Kareiva; P.; Neubert, M.G. (2004). Habitat destruction, fragmentation, and disturbance promote invasion by habitat generalists in a multispecies metapopulation. Risk Analysis, Vol.24, 869-878.

Materna, J.; Daniel, M. \& Danielova, V. (2005). Altitudinal distribution limit of the tick Ixodes ricinus shifted considerably towards higher altitudes in central Europe: results of three years monitoring in the Krkonose Mts. (Czech Republic). Central European Journal of Public Health, Vol.13, 24-28.

McCallum, H. \& Dobson, A. (1995). Detecting disease and parasite threats to endangered species and ecosystems. Trends in Ecology and Evolution, Vol.10, 190-194.

McIntyre, K.M., Setzkorn, C.; Baylis, M., Waret-Szkuta, A.; Caminade, C.; Morse, A.P.; Akin, S-A.; Huynen, M.; Martens, P. \& Morand S. (2010). Impact of climate change on human and animal health. Veterinary Record: 586

MEA (2005). Millenium Ecosystem Assessment. Ecosystems and Human Well-being: Biodiversity Synthesis. Island Press, Washigton DC.

Meffe, G.K. (1999). Conservation medicine. Conservation Biology, Vol.13, 953.

Meerburg, B.G.; Singleton, G.R.; Kijlstra, A. (2009). Rodent-borne diseases and their risks for public health. Critical Reviews in Microbiology, Vol.35, 221-70.

Mills, J.N. (2006). Biodiversity loss and emerging infectious disease: An example from the rodent-borne hemorrhagic fevers. Biodiversity, Vol.7, 9-17.

Milner-Gulland, E.J. \& Bennett, E.L. (2003). Wild meat: the bigger picture. Trends in Ecology and Evolution, Vol.18, 351-357.

Mitchell, C.E. \& Power, A.G. (2003). Release of invasive plants from fungal and viral pathogens. Nature, Vol.421, 625-627.

Møller, A.P. \& Cassey, P. (2004). On the relationship between T-cell mediated immunity in bird species and the establishment success of introduced populations. Journal of Animal Ecology, Vol.73, 1035-1042.

Molyneux, D.H.; Ostfeld, R.S.; Bernstein, A. \& Chivian, E. (2008). Ecosystem disturbance, biodiversity loss, and human infectious disease, In: Sustaining life : how human health depends on biodiversity, E. Chivian \& A. Bernstein (Eds), 287-323, Oxford University Press.

Morand, S. (2000). Wormy world: comparative tests of theoretical hypotheses on parasite species richness. In Evolutionary biology of host-parasite relationships: Theory meets reality (Poulin R, Morand S, Skorping A, eds), pp 63-79. Elsevier, Amsterdam.

Morand, S. \& Harvey, P. (2000). Mammalian metabolism, longevity and parasite species richness. Proceedings of the Royal Society London B, Vol.267, 1999-2003.

Morand, S. \& Poulin, R. (1998). Density, body mass and parasite species richness of terrestrial mammals. Evolutionnary Ecology, Vol.12, 717-727.

Moore, S.L. \& Wilson, K. (2002). Parasites as a viability cost of sexual selection in natural populations of mammals. Science, Vol.297: 2015-2018.

Mouritsen, K.N. \& Poulin R. (2002). Parasitism, climate oscillations and the structure of natural communities. Oikos, Vol.97, 462-468.

Mouritsen, K.N.; Tompkins, D.E. \& Poulin, R. (2005). Climate warming may cause a parasite-induced collapse in coastal amphipod populations. Oecologia, Vol.146, 476483. 
Nunn, C.L.; Altizer, S.; Jones, K.E. \& Sechrest, W. (2003). Comparative tests of parasites species richness in primates. The American Naturalist, Vol.162, 597-614.

Nunn, C.; Altizer, S.; Jones, K.E.; Sechrest, W. \& Cunningham, A.A. (2005). Latitudinal gradients of parasite species richness in primates. Diversity and Distributions, Vol.11: 249-56.

O’Brien, S.J.; Roelke, M.E.; Marker, L.; Newman, A.; Winkler, C.A. et al. (1985). Genetic basis for species vulnerability in the cheetah. Science, Vol. 227: 1428-1434.

Ostfeld, R. S. \& Keesing, F. (2000). Biodiversity and disease risk: The case of Lyme disease. Conservation Biology, 14:722-728.

Packer, C.; Holt, R.D.; Hudson, P.J.; Lafferty, K.D. \& Dobson, A.P. (2003). Keeping the herds healthy and alert: implications of predator control for infectious disease. Ecology Letters, Vol.6, 797-802.

Patz, J.A.; Daszak, P.; Tabor, G.M.; Aguirre, A.A.; Pearl, M. et al. (2004). Unhealthy landscapes: policy recommendations on land use change and infectious disease emergence. Environmental Health Perspectives, Vol.112, 1092-98.

Patz, J.A.; Epstein, P.R.; Burke, T.A. \& Balbus, J.M. (1996).-Global climate change and emerging infectious diseases. Journal of the American Medical Association, Vol.275, 217-223.

Patz, J.A.; Graczyk, T.K.; Geller, N. \& Vittor, A.Y. (2000). Effects of environmental change on emerging parasitic diseases. International Journal for Parasitology, Vol.30, 1395-1405.

Patz, J.A.; Hulme, M.; Rosenzweig, C.; Mitchell, T.D.; Goldberg, R.A.; Githeko; A.K.; Lele, S.; McMichael, A.J. \& Le Sueur, D. (2002). Climate change: Regional warming and malaria resurgence. Nature, Vol.420, 627-628.

Pedersen, A.B. \& Fenton, A. (2006). Emphasizing the ecology in parasite community ecology. Trends in Ecology and Evolution, Vol.22, 133-139.

Peterson, A.T.; Sanchez-Cordero, V.; Beard, C.B. \& Ramsey, J.M. (2002). Ecologic niche modeling and potential reservoirs for Chagas disease, Mexico. Emerging Infectious Diseases, Vol.8, 662-667.

Peterson, A.T.; Pereira, R.S. \& Neves, V.F. (2004a). Using epidemiological survey data to infer geographic distributions of leishmaniasis vector species. Revista da Sociedade Brasileira de Medicina Tropical, Vol.37, 10-14.

Peterson, A.T., Bauer J.T. \& Mills J.N. (2004b). Ecologic and geographic distribution of filovirus disease. Emerging Infectious Diseases, 10, 40-47.

Pounds, J.A.; Fogden, P.L.; Savage, J.M. \& Gorman, G.C. (1997). Test of null models for amphibian declines on a tropical mountain. Conservation Biology, Vol.11, 1307-1322.

Poulin, R. (1995). Phylogeny, ecology, and the richness and parasite communities in vertebrates. Ecological Monograph, Vol. 65, 283-302.

Poulin, R. (2006). Global warming and temperature-mediated increases in cercarial emergence in trematode parasites. Parasitology, Vol.132, 143-151.

Poulin, R. \& Morand, S. (2004). The parasite biodiversity. Smithsonian Institution Press, Washington.

Raymundo, L. J.; Halforda, A.R.; Maypab, A.P. \& Kerr, A.M. (2009). Functionally diverse reef-fish communities ameliorate coral disease. Proc. Natl Acad. Sci. USA, Vol.106, 17067-17070.

Rayner, J.C.; Liu, W.;Peeters, M.; Sharp; P.M. \& Hahn B.H. (2011). A plethora of Plasmodium species in wild apes: a source of human infection? Trends in Parasitology; Vol.27: 222-229. 
Randolph, S.E. (2001). The shifting landscape of tick-borne zoonoses: Tick-borne encephalitis and Lyme borreliosis in Europe. Proceedings of the Royal Society B-Biological Sciences, Vol.356, 1045-1056.

Rogers, D.J. \& Randolph, S.E. (2000). The global spread of malaria in a future, warmer world. Science, Vol.289, 1763-1766.

Rushton, S.P.; Lurz, P.W.W.; Gurnell, J. \& Fuller, R. (2000). Modelling the spatial dynamics of parapoxvirus disease in red and grey squirrels: a possible cause of the decline in the red squirrel in the UK? Journal of Applied Ecology, Vol.37, 997-1012.

Saul, A. (2003). Zooprophylaxis or zoopotentiation: the outcome of introducing animals on vector transmission is highly dependent on the mosquito mortality while searching. Malaria Journal, Vol.2, 32-50.

Schmitz, O.J. \& Nudds, T.D. (1994). Parasite-mediated comp etition in deer and moose: how strong is the effect of meningeal worm on moose? Ecological Applications, Vol.4, 91103.

Scholte, E.J. \& Schaffner, F. (2007). Waiting for the tiger: establishment and spread of the Aedes albopictus mosquitoes in Europe. In: Emerging pests and vector-borne diseases in Europe, W. Takken \& B.G.J., Knols (Eds), 241-260, Wageningen Academic Publisher.

Shope, R. (1991). Global climate change and infectious diseases. Environmental Health Perspectives, Vol.96, 171-174.

Smart, S.M.; Thompson, K.; Marrs, R.H. et al. (2006). Biotic homogenization and changes in species diversity across human-modified ecosystems. Proceedings of the Royal Society B-Biological Sciences, Vol.273, 2659-2665.

Sprent, J.F.A. (1992). Parasites lost? International Journal for Parasitology, Vol.22, 139-151.

Stanko, M.; Miklisová, D.; Goüy de Bellocq, J. \& Morand, S. (2002). Mammal density and patterns of ectoparasite species richness and abundance. Oecologia, Vol.131, 289-295.

Stenseth, N.C.; Mysterud, A.; Ottersen, G.; Hurrell, J.W.; Chan, K.-S. \& Lima, M. (2002). Ecological effects of climate fluctuations. Science, Vol.297, 1292-1296.

Sutherst, R.W. (1998). Implications of global change and climate variability for vector-borne diseases: Generic approaches to impact assessments. International Journal for Parasitology, Vol.28, 935-945.

Sutherst, R.W. (2001). The vulnerability of animal and human health to parasites under global change. International Journal for Parasitology, Vol.31, 933-948.

Sutherst, R.W. (2004). Global change and human vulnerability to vector-borne diseases. Clinical Microbiological Review, Vol.17, 136-173.

Suzán, G.; Marcé, E.; Giermakowski, J.T., Mills, J.N.; Ceballos, G. et al. (2009). Experimental evidence for reduced rodent diversity causing increased Hantavirus prevalence. Plos ONE, Vol.4, e5461.

Swaddle, J.P. \& Calos, S.E. (2008). Increased avian diversity is associated with lower incidence of human West Nile infection: Observation of the dilution effect. PLoS ONE, Vol.3, e2488.

Tersago, K.; Schreurs, A.; Linard, C.; Verhagen, R.; Dongen, S.V. \& Leirs, H. (2008). Population, environmental, and community effects on local bank vole (Myodes glareolus) Puumala virus infection in an area with low human incidence. VectorBorne and Zoonotic Diseases, Vol.8, 235-244.

Thieltges, D.W., Bordalo, M.D., Caballero-Hernandez, A., Prinz, K. \& Jensen, K.T. (2008). Ambient fauna impairs parasite transmission in a marine parasite-host system. Parasitology, Vol.135, 1111-1116.

Thieltges, D.W.; Reise, K.; Prinz, K. \& Jensen, K.T. (2009). Invaders interfere with native parasite-host interactions. Biological Invasions, Vol.11, 1421-1429. 
Thomas, F.; Poulin, R.; de Meeüs, T.; Guégan, J.-F. \& Renaud, F. (1999). Parasites and ecosystem engineering: What roles could they play? Oikos, Vol.84, 167-171.

Torchin, M.E.; Lafferty, K.D.; Dobson, A.P.; McKenzie, V.J. \& Kuris, A.M. (2003). Introduced species and their missing parasites. Nature; Vol.421, 628-630.

Torres, J.; Miquel, J.; Casanova, J.-C.; Ribas, A.; Feliu, C. \& Morand, S. (2006). Parasite species richness of Iberian carnivores: influences of host density and range distribution. Biodiversity and Conservation, Vol.15, 4619-4632

Thorne, E.T. \&Williams, E.S. (1988). Disease and endangered species: the black-footed ferret as a recent example. Conservation Biology, Vol.2, 66-74.

Torres, J.; Miquel, J.; Casanova, J.C.; Ribas, A.; Feliu, C. \& Morand, S. (2006). Parasite species richness of Iberian carnivores: influences of host density and range distribution. Biodiversity and Conservation, Vol.15: 4619-4632.

van Riper, C.; van Riper, S.G.; Goff, M.L. \& Laird, M. (1986). The epizootiology and ecological significance of malaria in Hawaiian land birds. Ecological Monographs, Vol.56, 327-344.

van Riper, C.; van Riper, S.G. \& Hansen, W.R. (2002). Epizootiology and effect of avian pox on Hawaiian forest birds. The Auk, Vol.119, 929-942.

Vitousek, P.M.; Dantonio, C.M.; Loope, L.L.; Rejmanek, M. \& Westbrooks, R. (1997). Introduced species: a significant component of human-caused global change. New Zealand Journal of Ecology, Vol.21, 1-16.

Vittor, A.Y., Gilman, R.H., Tielsch, J., et al. (2006). The effect of deforestation on the humanbiting rate of Anopheles darlingi, the primary vector of Falciparum malaria in the Peruvian Amazon. American Journal of Tropical Medicine and Hygiene, Vol.74, 3-11.

Vourc'h, G.; Marmet, J.; Chassagne, M.; Bord, S. \& Chapuis, J.-L. (2007). Borrelia burgdorferi sensu lato in Siberian chipmunks (Tamias sibiricus) introduced in suburban forests in France. Vector-Borne and Zoonotic Diseases, Vol.7, 637-641.

Walpole, M.; Almond, R.E.; Besançon, C.; Butchart, S.H.; Campbell-Lendrum, D. et al. (2009). Ecology. Tracking progress toward the 2010 biodiversity target and beyond. Science, Vol.325 5947

Walther, G.-R.; Post, E.; Convey, P.; Menzel, A.; Parmesan, C. et al. (2002). Ecological responses to recent climate change. Nature, Vol.416, 389-395.

White, P.C.L.; Newton-Cross, G.A.; Gray, M.; Ashford, R.; White, C. \& Saunders, G. (2003). Spatial interactions and habitat use of rabbits on pasture and implications for the spread of rabbit haemorrhagic disease in New South Wales. Wildlife Research, Vol.30, 49-58.

Wilcox, B.A. \& Gubler, D.J. (2005). Disease ecology and the global emergence of zoonotic pathogens. Environmental Health and Preventive Medicine, Vol.10, 263-272.

Williamson, M. (1996). Biological invasions. Chapman and Hall, London

Wilson, M.E. (2000). Environmental change and infectious diseases. Ecosystem and Health, Vol.6, 8-12.

Wolfe, N. D., Daszak, P., Kilpatrick, A.M. \& Burke, D.S. (2005). Bushmeat hunting, deforestation and prediction of zoonotic emergence. Emerging Infectious Diseases, Vol.11, 1822-1827. 


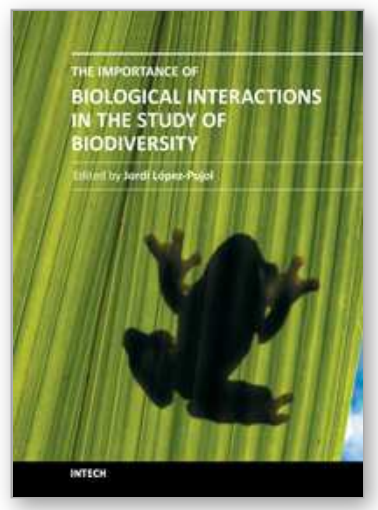

\section{The Importance of Biological Interactions in the Study of Biodiversity}

Edited by Dr. Jordi LÃ $\tilde{\beta}^{3}$ ez-Pujol

ISBN 978-953-307-751-2

Hard cover, 390 pages

Publisher InTech

Published online 22, September, 2011

Published in print edition September, 2011

The term biodiversity defines not only all the variety of life in the Earth but also their complex interactions. Under the current scenario of biodiversity loss, and in order to preserve it, it is essential to achieve a deep understanding on all the aspects related to the biological interactions, including their functioning and significance. This volume contains several contributions (nineteen in total) that illustrate the state of the art of the academic research in the field of biological interactions in its widest sense; that is, not only the interactions between living organisms are considered, but also those between living organisms and abiotic elements of the environment as well as those between living organisms and the humans.

\section{How to reference}

In order to correctly reference this scholarly work, feel free to copy and paste the following:

Serge Morand (2011). Infectious Diseases, Biodiversity and Global Changes: How the Biodiversity Sciences May Help, The Importance of Biological Interactions in the Study of Biodiversity, Dr. Jordi LÃpez-Pujol (Ed.), ISBN: 978-953-307-751-2, InTech, Available from: http://www.intechopen.com/books/the-importance-ofbiological-interactions-in-the-study-of-biodiversity/infectious-diseases-biodiversity-and-global-changes-howthe-biodiversity-sciences-may-help

\section{INTECH}

open science | open minds

\section{InTech Europe}

University Campus STeP Ri

Slavka Krautzeka 83/A

51000 Rijeka, Croatia

Phone: +385 (51) 770447

Fax: +385 (51) 686166

www.intechopen.com

\section{InTech China}

Unit 405, Office Block, Hotel Equatorial Shanghai

No.65, Yan An Road (West), Shanghai, 200040, China

中国上海市延安西路65号上海国际贵都大饭店办公楼 405 单元

Phone: +86-21-62489820

Fax: +86-21-62489821 
(C) 2011 The Author(s). Licensee IntechOpen. This chapter is distributed under the terms of the Creative Commons Attribution-NonCommercialShareAlike-3.0 License, which permits use, distribution and reproduction for non-commercial purposes, provided the original is properly cited and derivative works building on this content are distributed under the same license. 